\title{
NUTM2A wt Allele
}

National Cancer Institute

\section{Source}

National Cancer Institute. NUTM2A wt Allele. NCI Thesaurus. Code C101099.

Human NUT M2A wild-type allele is located in the vicinity of 10q23.2 and is approximately $14 \mathrm{~kb}$ in length. This allele, which encodes NUT family member 2A protein, has an unknown function. A translocation $\mathrm{t}(10 ; 17)(\mathrm{q} 22-23 ; \mathrm{p} 13)$ that fuses this gene with the YWHAE gene is associated with high-grade uterine endometrial stromal sarcoma. 